\title{
A Demand Survey on the Priority of Agricultural College Students' Core Competencies Required by Agricultural Companies: A case study on G University
}

\author{
Yumin Park ${ }^{1,3}$ and Yong-Wook Shin ${ }^{1,2,3^{*}}$ \\ ${ }^{1}$ Doctoral Student, Department of Plant Resources, Gyeongsang National University, Jinju 52725, Korea \\ ${ }^{2}$ Professor, Department of Plant \& Biomaterials science, Gyeongsang National University, Jinju 52725, Korea \\ ${ }^{3}$ Institute of Agriculture \& Life Science, Gyeongsang National University, Jinju 52828, Korea
}

\section{ABSTRACT}

Background and objective: As the agricultural industry becomes a more convergent industry, it is believed that the demand for human resources by companies will change. Therefore, a survey was conducted to investigate the human resources required by agriculture companies.

Methods: In the survey on 77 agriculture companies, $98.7 \%$ of respondents answered that new employees with a college degree needed additional training to adapt to practical affairs.

Results: The first priority of education was "community spirit" (22.1\%) and the second priority was "convergence capability" (15.6\%). The most important educational goal desired by agricultural companies was "cultivating human resources with community spirit and ethical judgment", followed by "cultivating human resources with serious communication and problem-solving skills", and "cultivating human resources with scientific thinking and unique creative imagination." Sub-competencies that companies want agricultural colleges to strengthen were "community spirit" 4.32(SD=0.96), "desirable values" 4.30 (SD = 1.05), "sympathy" 4.28 (SD = 0.95), "convergence capability" $4.16(S D=0.88)$, "creativity" 4.11 (SD = 0.83), "civic spirit" 4.10 (SD = 0.91), and "rational/critical thinking" $3.94(\mathrm{SD}=1.04)$. There was a significant difference in sub-competencies that require reinforcement depending on the number of full-time employees. "Creativity" was most necessary in companies with less than 3 employees (4.39), and 4 7 employees (4.33), and "aesthetics" in companies with less than 3 employees (3.94), and 4-7 employees (3.61) "Civic spirit" was most necessary in companies with 31 employees or more (4.33).

Conclusion: The most important educational goal desired by companies was "cultivating human resources with community spirit and ethical judgment".

Keywords: agricultural company, core competency, community spirit, survey

\section{Introduction}

\section{Introduction}

Efforts for the 6th industrialization are being made for agriculture in Korea to enhance agricultural competitiveness for cultivation, processing, and distribution of agricul- tural products led by farmers through convergence of primary, secondary, and tertiary industries (Kim et al., 2015). In fact, the industrial structure in rural areas has changed rapidly over the last 10 years or so, and the share of primary industries decreased by $18.5 \%$ from $46.9 \%$ in 2000 to $28.4 \%$ in 2013 , whereas that of secondary and tertiary industries increased by $11.7 \%$ and $7.8 \%$. In particular,

This work was supported by the research invigoration program of 2020 Gyeongnam National University of Science and Technology. Received: June 8, 2021, Revised: June 24, 2021, Accepted: July 14, 2021

First author: Yumin Park, cocoyumin@naver.com, (D) https://orcid.org/0000-0002-8483-3290

*Corresponding author: Yong-Wook Shin, ywsynn@gnu.ac.kr, (1) https://orcid.org/0000-0002-4983-0107 
$13.3 \%$ of agricultural college graduates entered the agricultural industry, and $3.6 \%$ started business in the agro-industry, showing that agricultural colleges contribute greatly to not only nurturing farmers but also fields that require agricultural background such as starting business in the agro-industry. Many of those starting business in the agro-industry were cooking majors $(25.0 \%)$ and food and nutrition majors $(23.1 \%)$, indicating that there is a strong tendency of the 6th industrialization through business start-up of traditional foods and farmhouse restaurants (Kim and Bae, 2014). Efforts are also made overseas for interdisciplinary education in agriculture at institutions of higher education (Bryant et al., 2014; Valley et al., 2018), perceiving the integrated thinking skills of students as a core competency (Hilimire et al., 2014). The growth potential of the agro-industry can be promoted with convergence education by breaking free from the conventional idea that focuses on manufacturing of agricultural products (Lee, 2018).

College students today preparing for the era of the 4th Industrial Revolution must flexibly cope with change and cultivate core competencies to integrate knowledge rather than having specific skills or knowledge (Kim and Kim, 2017). The current trend of curriculum reform is led by various studies and practices to create a new framework with focus on 'competencies' (Lee and So, 2019). The DeSeCo (Definition and Selection of Competencies) project by the OECD referred to competencies that can be applied to a wide variety of contexts and are necessary for all individuals as 'key competencies' (OECD, 2005). Here, competency is defined as "the ability to successfully meet complex demands in a particular context through the mobilization of not only knowledge and cognitive/practical skills but also social and behavioral elements such as attitudes, emotions, values, and motives" (Rychen, 2003, as cited in Lee and So, 2019). The concept of competency used in vocational skills associated competency with the entire human life by DeSeCo and made people realize the importance of competency (So, 2007). Core competencies are defined as cognitive, emotional, and social skills necessary for learners to achieve success and competitive advantages at present or in the near future in their education or vocational life (Boyatzis, 2008). Core competencies of college students mostly indicate the basic and universal abilities that must be improved by college education (Baek, 2013) based on soft skills associated with cognitive skills as well as noncognitive skills such as academic knowledge, problem solving, communication, self-improvement, and management (Adams, 2012). As job competencies are changing so that they include the skills and attitudes to connect to individual task performance (Jin et al., 2011), college education also defined core competencies as the complex abilities to live as a member of the society by combining knowledge and practice for college students (Park and Song 2016).

Accordingly, through the Advancement of College Education (ACE) project and the college basic competency diagnosis project, the Ministry of Education demanded that colleges reflect core competencies on the educational objectives and ideal talent and organize and operate competency-based curriculums. In particular, curriculums for majors are required to 'describe in priority the effects of enhancing student competencies by organizing and operating curriculums for majors that meet the ideal talent requirements of the society as well as college characteristics' (Paek, 2020). The purpose of competency-based curriculums is to improve student performance by adopting practice-based education (Oh, 2012). Colleges are diagnosing core competencies according to student characteristics such as program, major, admission type, and year and using them as the basic data to find and suggest improvement points of the education policy (Lee and Kim, 2018).

A study was recently conducted on competencies required by each school, and dental schools included sympathy through communication as an element (Hwang, 2020), while nursing schools must open courses on communication and human relations in the curriculum and establish a program to improve interpersonal relations as an extracurricular course for core nursing competency (Park et al., 2015).

As a result of analyzing the demand and priorities of core competency education to examine core competencies of college liberal arts courses for ideal talent required by companies, the competencies showing highest educational demand were foreign language skills in global competencies, character cultivation in liberal arts knowledge, and self-exploration and improvement (Kim and Seong, 2017). A sur- 
vey about core competencies conducted on 300 small and mid-sized enterprises (SMEs) revealed that the most required competencies were interpersonal relations and self-management competencies (Oh, 2012). Studies overseas reported that the competency showing highest demand among 58 competencies obtained based on consultation with agro-industry experts was not agricultural skills but soft skills (Colclasure, 2020). However, in Korea, core competencies in college education demanded by agriculture-related companies have never been surveyed.

Accordingly, it is necessary to determine the ideal talent desired by agriculture companies to cultivate human resources for future agriculture and apply that to educational settings, which is why this study is conducted. The results will contribute to completing an agricultural education model that meets the demands on site.

\section{Theoretical review}

\section{Core competencies at G University}

The Korea Collegiate Essential Skills Assessment (K-CESA) scale by Korea Research Institute for Vocational Education and Training is comprised of 6 core competencies: communication, global, resource-information-technology utilization, comprehensive thinking, interpersonal relations, and self-management competencies (Jin et al. 2011). The scale was developed according to the ideal talent of $\mathrm{G}$ University with differentiation from the subfactors of core competencies in K-CESA. We came up with competencybased education goals in the founding philosophy of self-awareness, exploration, and practice and set goals in alignment with core competencies, which are the power internalized by human resources through education. In other words, we set the goal for self-awareness as cultivating ethical experts with community spirit and ethical judgment, for exploration as cultivating defiant human resources with scientific thinking and unique creative imagination, and for practice as cultivating creative actors with serious communication and problem-solving skills.

\section{Definition of competency}

The core competency model is referred to as SUCCESS using the initials of six competencies such as scientific thinking, unique creative imagination, community spirit, ethical judgment, serious communication, and solving problems.

(1) Scientific thinking: This competency can determine the reality through rational/critical introspection and systematically understand the phenomenon using a scientific methodology. Agricultural colleges defined this as the ability to comprehensively determine all kinds of expertise in the bioindustry and systematically understand the phenomenon using a scientific methodology. Sub-competencies of scientific thinking are rational/critical thinking and computing thinking.

(2) Unique creative imagination: This competency can precisely diagnose various real-life problems and mobilize creative and psychological sensibility to come up with solutions in original ways. Agricultural colleges defined this as the creative ability to create new values by approach the problem from various perspectives in the bioindustry and finding solutions.

(3) Community spirit: This competency can create social issues out of various social and cultural phenomena beyond individuals and form solidarity with members to provide solutions. Agricultural colleges defined this as the ability to create social issues out of various social phenomena in terms of bioindustry and provide solutions by forming solidarity with members based on the above. Sub-competencies of community spirit are community spirit and civic spirit.

(4) Ethical judgment: This competency can establish proper views of the world, humans and values at the individual level and reciprocally share the thoughts and emotions of members. Agricultural colleges defined this as the ability to establish proper views of the world, humans and values as bioindustry experts and share the thoughts and emotions of members about ethical practices. Sub-competencies of ethical judgment are desirable values and sympathy.

(5) Serious communication: This competency can accept acts, opinions, and arguments of others or diverse cultures without prejudice and clearly express one's principles and arguments by reinterpreting them from their own perspective. Agricultural colleges defined this as the ability to accept a acts, opinions, and arguments in various fields and clearly express one's ar- 
guments by reinterpreting them from their own perspective. Sub-competencies of serious communication are universal literacy and international communication.

(6) Solving problems: This competency can freely explore new topics based on one's awareness and interest and create valuable meaning through convergent thinking for problem solving. Agricultural colleges defined this as the ability to freely explore new topics based on one's knowledge and interest in bioindustry and create valuable results through convergent thinking for problem solving. Sub-competencies of solving problems are self-directed exploration and convergence capability.

\section{Research Methods}

\section{Research design and subjects}

\section{Research design}

Learning needs analysis on college graduates in the agro-industry was conducted according to the procedures of establishing the analytical framework, developing the tool, conducting the survey, and analyzing the results. We came up with the first draft of the analytical framework based on literature review and established the framework. Based on the framework, we created the first draft of the questionnaire based on literature analysis and finalized the questionnaire by revising and supplementing the first draft through meetings. The final questionnaire was comprised of items rated on a 5-point Likert scale depending on their characteristics, including industry, location, and firm size aside from contents of analysis.

\section{Subjects}

To determine the core competencies of college students required by the agro-industry, we conducted an offline survey on CEOs and employees of companies that participated in the Jinju International Agriculture \& Food Expo from November 3 to 11,2018 . Then we conducted an online survey on middle-aged female farmer CEOs using the Google Forms and used 77 cases in the analysis excluding insincere responses (Table 1).
Most of the companies were located in Busan / Daegu / Ulsan / Gyeongsang-do (65, 84.4\%), followed by Gwangju / Jeolla-do (11, 14.3\%) and Gangwon-do / Jeju-do (1, 1.3\%). Most companies had less than 3 full-time employees (33, $42.9 \%)$, followed by 4-7 employees $(18,23.4 \%) 8-20 \mathrm{em}-$ ployees $(15,19.5 \%), 31$ employees $(9,11.7 \%)$, and 21-less than 30 employees $(2,2.6 \%)$. As for the operating type based on the agro-industry (6th industry), there were cultivation + processing + distribution $(35,45.5 \%)$, others $(14$, $18.2 \%)$, cultivation + distribution $(9,11.7 \%)$, distribution $(6,7.8 \%)$, cultivation + processing $(5,6.5 \%)$, cultivation

Table 1. Respondent's Demographic Analysis Results

$\mathrm{N}=77$

\begin{tabular}{|c|c|c|}
\hline Questions & Answers & $\begin{array}{c}\text { Respondent } \\
\mathrm{s}(\%)\end{array}$ \\
\hline \multirow{3}{*}{$\begin{array}{l}\text { Company } \\
\text { location }\end{array}$} & Jeolla Province & 14.3 \\
\hline & Gyeongsang Province & 84.4 \\
\hline & Gangwon/Jeju Province & 1.3 \\
\hline \multirow{5}{*}{$\begin{array}{l}\text { No. of } \\
\text { full time } \\
\text { employees }\end{array}$} & $\leq 3$ & 42.9 \\
\hline & $4-7$ & 23.4 \\
\hline & $8-20$ & 19.5 \\
\hline & $21-30$ & 2.6 \\
\hline & $\geq 31$ & 11.7 \\
\hline \multirow{8}{*}{$\begin{array}{c}\text { Agricultural } \\
\text { industry } \\
\text { Type }\end{array}$} & Cultivation+Processing & 6.5 \\
\hline & Cultivation+Distribution & 11.7 \\
\hline & Cultivation+Processing+Distribution & 45.5 \\
\hline & Cultivation only & 5.2 \\
\hline & Processing on;y & 2.6 \\
\hline & Distribution only & 7.8 \\
\hline & Service & 2.6 \\
\hline & Etc. & 18.2 \\
\hline \multirow{7}{*}{$\begin{array}{l}\text { Product and } \\
\text { service } \\
\text { Items of } \\
\text { Agricultural } \\
\text { industry }\end{array}$} & Agricultural products & 28.6 \\
\hline & Processed food & 22.1 \\
\hline & Direct sales & 6.5 \\
\hline & Experience Tour & 3.9 \\
\hline & Distribution & 6.5 \\
\hline & Service & 1.3 \\
\hline & Etc. & 31.2 \\
\hline \multirow{5}{*}{ Firm type } & Private Farm/Company & 45.5 \\
\hline & Agricultural company corporations & 20.8 \\
\hline & Agricultural association corporation & 10.4 \\
\hline & Joint-stock corporation & 9.1 \\
\hline & Etc. & 14.3 \\
\hline
\end{tabular}


(4, 5.2\%), and processing and service (2 each, 2.6\%). For product and service items, most responded others (31.2\%), followed by agricultural products $(28.6 \%)$, processed food $(22.1 \%)$, distribution and direct sales $(6.5 \%)$, and experience tour $(3.9 \%)$. The type of most companies was private farms/companies (45.5\%), followed b agricultural corporations $(20.8 \%)$, others $(14.3 \%)$, agricultural associations (10.4\%), and joint-stock corporations (9.1\%).

\section{Methods}

\section{Reliability and validity testing of the questionnaire}

For factor extraction, we conducted principal axis factor- ing and varimax rotation. Factor analysis was conducted using total 15 items. KMO measure was .832, and the Bartlett's test of sphericity showed the p-value below .05, proving that the factor analysis model is fit. Meanwhile, cumulative variance was $66.323 \%$, and thus the explanatory power of the two factors was high (Table 2).

The first factor included 12 items, and the second factor included 3 items. Based on the contents, the first factor was named competency education enhancement, and the second educational goals. Factor loadings were all over 0.4, satisfying the validity of the measurement tool overall, and analysis was conducted without additional item exclusion or adjustment (Table 3).

Table 2. Explanatory factor analysis

\begin{tabular}{|c|c|c|c|}
\hline & \multirow{2}{*}{ Item } & \multicolumn{2}{|c|}{ Factor } \\
\hline & & 1 & 2 \\
\hline & Rational critical thinkings & .804 & .240 \\
\hline & Computing thinkings & .794 & .114 \\
\hline & Creativity & .769 & .122 \\
\hline & Aesthetics & .665 & .202 \\
\hline & Community spirit & .648 & .325 \\
\hline & Civic spirit & .626 & .148 \\
\hline & Desirable values & .577 & .433 \\
\hline & Sympathy & .556 & .226 \\
\hline & Universal literacys & .538 & .331 \\
\hline & International communication & .489 & .280 \\
\hline & Self-directed exploration & .393 & .366 \\
\hline & Convergence capability & .321 & .110 \\
\hline & Community Spirit and Ethical judgment. & .021 & .963 \\
\hline $\begin{array}{l}\text { Cultivatıng human } \\
\text { resources with }\end{array}$ & Scientific thinking and Unique Creative imaginaion & .213 & .743 \\
\hline & Serious Communication and problem-solving skills & .321 & .691 \\
\hline & Eigen Value & 4.694 & 31.291 \\
\hline & $\%$ of Variance & 3.022 & 51.439 \\
\hline & $\%$ of Cum. Variance & 41.965 & 66.323 \\
\hline
\end{tabular}

Table 3. Reliability Analysis of Measuring Tools

\begin{tabular}{ccccc}
\hline & Variables & & Cronbach's Alpha & No. of Questionnaire \\
\hline \multirow{2}{*}{ Core competencies } & & Educational goals & .887 & 3 \\
& & subcompetence & .901 & 12 \\
& Firm type & & .842 & 5 \\
\hline \multirow{2}{*}{ Importance of Subcompetencies that need to be strengthened } & .793 & 3 \\
\hline
\end{tabular}


Reliability analysis was conducted to test the internal consistency. As a result of calculating Cronbach's alpha, all was over 0.7 , proving that all key variables had favorable reliability. Therefore, there were no items that inhibited reliability, and thus analysis was conducted without eliminating any items.

\section{Data processing method}

All results were statistically analyzed using SPSS 25.0. We first analyzed descriptive statistics on all survey items, conducted cross-tabulation analysis to verify the correlation among variables, extracted common factors through exploratory factor analysis on measurement variables by firm size, and conducted principal axis factoring and varimax rotation. Moreover, one-way ANOVA and Scheffe post-hoc test were conducted to examine the difference in competencies that need to be enhanced by firm size. The sig- nificance level of all analyses was $\alpha=.05$.

\section{Results and Discussion}

\section{Descriptive statistics of variables}

To the question, "Do new employees with a college degree need additional training to adapt to practical affairs?", $76(98.7 \%)$ out of 77 respondents said "yes" and 1.3\% said "no".

If additional training was needed, the respondents were to choose the top two most important types of training in the order of importance. The first priority was "community spirit" (22.1\%), "rational/critical thinking" (18.2\%), and "desirable values" (14.3\%). The second priority was "convergence capability" (15.6\%), "rational/critical thinking" (14.3\%), and "self-directed exploration" (13.0\%) (Table 4).

Table 4. Demographic characteristics

$N=77$

\begin{tabular}{|c|c|c|}
\hline Questions & Answers & Respondents(\%) \\
\hline \multirow{2}{*}{$\begin{array}{l}\text { The need for additional training to } \\
\text { adapt to practice }\end{array}$} & Yes & 98.7 \\
\hline & No & 1.3 \\
\hline \multirow{11}{*}{$\begin{array}{l}\text { The first priority } \\
\qquad(\mathrm{N}=76)\end{array}$} & Rational critical thinking & 18.2 \\
\hline & Computing thinking & 5.2 \\
\hline & Creativity & 11.7 \\
\hline & Aesthetics & 1.3 \\
\hline & Community spirit & 22.1 \\
\hline & Desirable values & 14.3 \\
\hline & Sympathy & 9.1 \\
\hline & Universal literacy & 3.9 \\
\hline & International communication ability & 1.3 \\
\hline & Self-directed exploration ability & 6.5 \\
\hline & Convergence capability & 5.2 \\
\hline \multirow{11}{*}{$\begin{array}{l}\text { The Second priority } \\
\qquad(\mathrm{N}=76)\end{array}$} & Rational critical thinking & 14.3 \\
\hline & Computing thinking & 7.8 \\
\hline & Creativity & 7.8 \\
\hline & Community spirit & 11.7 \\
\hline & Civic spirit & 1.3 \\
\hline & Desirable values & 11.7 \\
\hline & Sympathy & 6.5 \\
\hline & Universal literacy & 6.5 \\
\hline & International communication ability & 2.6 \\
\hline & Self-directed exploration ability & 13.0 \\
\hline & Convergence capability & 15.6 \\
\hline
\end{tabular}


As a result of assessing the importance of the three educational goals at $\mathrm{G}$ University in terms of human resources and task performance skills required by each company (Table 5), most responded that "cultivating human resources with community spirit and ethical judgment" is very important (53 respondents, 68.8\%) and slightly important (14, $18.2 \%$ ), and "cultivating human resources with scientific thinking and unique creative imagination" is slightly important $(30,39.0 \%)$ and very important $(28,36.4 \%)$. The respondents said that "cultivating human resources with serious communication and problem-solving skills" is very important $(46,59.7 \%)$ and slightly important $(18,23.4 \%)$.

Descriptive statistics were analyzed to examine the importance of the three items (Table 6). The mean of "cultivating human resources with community spirit and ethical judgment" was 4.34 (SD = 1.19), "cultivating human resources with scientific thinking and unique creative imagination" was $3.90( \pm=1.16)$, and "cultivating human resources with serious communication and problem-solving skills" was $4.25(\mathrm{SD}=1.13)$.

The item with highest importance was "cultivating human resources with community spirit and ethical judgment", followed by "cultivating human resources with serious communication and problem-solving skills" and "cultivating human resources with scientific thinking and unique creative imagination."

Cross-tabulations were calculated to test the difference in the importance depending on the number of full-time employees (Table 7). As a result, companies with less than 3 employees (31.2\%), 4-7 employees (16.9\%), 8-20 employees $(11.7 \%)$, and 31 employees or more $(7.8 \%)$ responded that cultivating human resources with community spirit and ethical judgment is very important, and those with 21-30 employees responded that it is very important $(1.3 \%)$ or

Table 5. Descriptive statistics of importance by Educational goals

\begin{tabular}{|c|c|c|}
\hline Educational goals & Necessity & Respondents(\%) \\
\hline \multirow{5}{*}{$\begin{array}{l}\text { Cultivating human resources with Community } \\
\text { Spirit and Ethical judgment. }\end{array}$} & Very unnecessary & 7.8 \\
\hline & Unnecessary & 0.0 \\
\hline & Neutral & 5.2 \\
\hline & Necessary & 18.2 \\
\hline & Very necessary & 68.8 \\
\hline \multirow{5}{*}{$\begin{array}{l}\text { Cultivating human resources with Scientific } \\
\text { thinking and Unique Creative imagination. }\end{array}$} & Very unnecessary & 6.5 \\
\hline & Unnecessary & 3.9 \\
\hline & Neutral & 14.3 \\
\hline & Necessary & 39.0 \\
\hline & Very necessary & 36.4 \\
\hline \multirow{5}{*}{$\begin{array}{l}\text { Cultivating human resources with Serious } \\
\text { Communication and problem-solving skills }\end{array}$} & Very unnecessary & 5.2 \\
\hline & Unnecessary & 2.6 \\
\hline & Neutral & 9.1 \\
\hline & Necessary & 23.4 \\
\hline & Very necessary & 59.7 \\
\hline
\end{tabular}

Table 6. Descriptive statistics of research variables

\begin{tabular}{ccccc}
\hline & Minimum value & Maximum value & Average & Standard deviation \\
\hline $\begin{array}{c}\text { Cultivating human resources with } \\
\text { Community Spirit and Ethical judgment. }\end{array}$ & 1 & 5 & 4.34 & 1.19 \\
$\begin{array}{c}\text { Cultivating human resources with Scientific } \\
\text { thinking and Unique Creative imagination }\end{array}$ & 1 & 5 & 3.90 & 1.16 \\
$\begin{array}{c}\text { Cultivating human resources with Serious } \\
\text { Communication and problem-solving skills. }\end{array}$ & 1 & 5 & 4.25 & 1.13 \\
\hline
\end{tabular}


slightly important (1.3\%).

Cultivating human resources with scientific thinking and unique creative imagination was considered very important in companies with less than 3 employees (19.5\%) and 4-7 employees (6.5\%), slightly important in companies with 8-20 employees (7.8\%) and 21-30 employees (2.6\%), and slightly important and very important in companies with 31 employees or more $(3.9 \%$ each $)$.
Cultivating human resources with serious communication and problem-solving skills was considered very important in companies with less than 3 employees (24.7\%), 4-7 employees (16.9\%), 8-20 employees (11.7\%), and 31 employees or more $(6.5 \%)$, and slightly important in companies with 21-30 employees (1.3\%).

The data given in Table 8 reveals the importance of educational goals according to the number of full time

Table 7. Descriptive statistics of importance by Educational goals according to the number of full time employees.

\begin{tabular}{|c|c|c|c|c|c|c|c|}
\hline & & \multicolumn{5}{|c|}{ Importance of cultivating human resources with community spirit and ethical judgment. } & \multirow{2}{*}{ Total } \\
\hline & & Very unnecessary & Unnecessary & Neutral & Necessary & Very necessary & \\
\hline \multirow{5}{*}{$\begin{array}{l}\text { No. of } \\
\text { full time } \\
\text { employees }\end{array}$} & $\leq 3$ & $3(3.9)$ & $0(0.0)$ & $1(1.3)$ & $5(6.5)$ & $24(31.2)$ & $33(42.9)$ \\
\hline & $4-7$ & $1(1.3)$ & $0(0.0)$ & $2(2.6)$ & $2(2.6)$ & $13(16.9)$ & $18(23.4)$ \\
\hline & $8-20$ & $2(2.6)$ & $0(0.0)$ & $0(0.0)$ & $4(5.2)$ & $9(11.7)$ & $15(19.5)$ \\
\hline & $21-30$ & $0(0.0)$ & $0(0.0)$ & $0(0.0)$ & $1(1.3)$ & $1(1.3)$ & $2(2.6)$ \\
\hline & $\geq 31$ & $0(0.0)$ & $0(0.0)$ & $1(1.3)$ & $2(2.6)$ & $6(7.8)$ & $9(11.7)$ \\
\hline \multicolumn{2}{|c|}{ Total } & $6(7.8)$ & $0(0.0)$ & $4(5.2)$ & $14(18.2)$ & $53(68.8)$ & $77(100)$ \\
\hline & & \multicolumn{5}{|c|}{ Importance of cultivating human resources with scientific thinking and unique creative imagination. } & \multirow{2}{*}{ Total } \\
\hline & & Very unnecessary & Unnecessary & Neutral & Necessary & Very necessary & \\
\hline \multirow{5}{*}{$\begin{array}{l}\text { No. of } \\
\text { full time } \\
\text { employees }\end{array}$} & $\leq 3$ & $3(3.9)$ & $0(0.0)$ & $4(5.2)$ & $11(14.3)$ & $15(19.5)$ & $33(42.9)$ \\
\hline & $4-7$ & $1(1.3)$ & $1(1.3)$ & $3(3.9)$ & $8(10.4)$ & $5(6.5)$ & $18(23.4)$ \\
\hline & $8-20$ & $0(0.0)$ & $2(2.6)$ & $2(2.6)$ & $6(7.8)$ & $5(6.5)$ & $15(19.5)$ \\
\hline & $21-30$ & $0(0.0)$ & $0(0.0)$ & $0(0.0)$ & $2(2.6)$ & $0(0.0)$ & $2(2.6)$ \\
\hline & $\geq 31$ & $1(1.3)$ & $0(0.0)$ & $2(2.6)$ & $3(3.9)$ & $3(3.9)$ & $9(11.7)$ \\
\hline \multicolumn{2}{|c|}{ Total } & $5(6.5)$ & $3(3.9)$ & $11(14.3)$ & $30(39.0)$ & $28(36.4)$ & $77(100)$ \\
\hline & & \multicolumn{5}{|c|}{ Importance of cultivating human resources with serious communication and problem-solving skills. } & \multirow{2}{*}{ Total } \\
\hline & & Very unnecessary & Unnecessary & Neutral & Necessary & Very necessary & \\
\hline \multirow{5}{*}{$\begin{array}{l}\text { No. of } \\
\text { full time } \\
\text { employees }\end{array}$} & $\leq 3$ & $3(3.9)$ & $0(0.0)$ & $2(2.6)$ & $9(11.7)$ & $19(24.7)$ & $33(42.9)$ \\
\hline & $4-7$ & $1(1.3)$ & $0(0.0)$ & $2(2.6)$ & $2(2.6)$ & $13(16.9)$ & $16(20.8)$ \\
\hline & $8-20$ & $0(0.0)$ & $2(2.6)$ & $1(1.3)$ & $3(3.9)$ & $9(11.7)$ & $8(10.4)$ \\
\hline & $20-30$ & $0(0.0)$ & $0(0.0)$ & $1(1.3)$ & $1(1.3)$ & $0(0.0)$ & $7(9.1)$ \\
\hline & $\geq 30$ & $0(0.0)$ & $1(1.3)$ & $1(1.3)$ & $3(3.9)$ & $5(6.5)$ & $11(14.3)$ \\
\hline \multicolumn{2}{|c|}{ Total } & $4(5.2)$ & $2(2.6)$ & $7(9.1)$ & $18(23.4)$ & $46(59.7)$ & 77 (100) \\
\hline
\end{tabular}

Table 8. The Importance of educational goals according to the number of full time employees.

\begin{tabular}{ccccccc}
\hline & & \multicolumn{5}{c}{ Number of full time employees } \\
\cline { 3 - 7 } & & $\leq 3$ & $4-7$ & $8-20$ & $21-30$ & $\geq 31$ \\
\hline & Cultivating human resources with & 4.42 & 4.44 & 4.20 & 4.50 & 4.56 \\
Community Spirit and Ethical judgment. & $( \pm 1.20)$ & $( \pm 1.10)$ & $( \pm 1.37)$ & $( \pm 0.71)$ & $( \pm 0.73)$ \\
Educational & Cultivating human resources with Scientific & 4.06 & 3.83 & 3.93 & 4.00 & 3.78 \\
goals & thinking and Unique Creative imagination & $( \pm 1.20)$ & $( \pm 1.10)$ & $( \pm 1.03)$ & $( \pm 0.00)$ & $( \pm 1.30)$ \\
& Cultivating human resources with Serious & 4.24 & 4.44 & 4.27 & 3.50 & 4.44 \\
& Communication and problem-solving skills. & $( \pm 1.20)$ & $( \pm 1.10)$ & $( \pm 1.10)$ & $( \pm 0.71)$ & $( \pm 0.73)$ \\
\hline
\end{tabular}


employees. Also, the importance of items related to college education that must be strengthened was rated on a 5-point Likert scale, and the results are provided in Table 9. By priority, "rational/critical thinking" was slightly necessary and very necessary (28 each, 36.4\%), "computing thinking" was slightly necessary $(31,40.3 \%)$ and neutral $(26,33.8 \%)$, "creativity" was slightly necessary $(37,48.1 \%)$ and very necessary (27, 35.1\%), "aesthetics" was neutral $(29,37.7 \%)$ and slightly necessary $(26,33.8 \%)$, "community spirit" was very necessary $(45,58.4 \%)$ and slightly necessary (19, $24.7 \%)$, "civic spirit" was very necessary $(31,40.3 \%)$ and slightly necessary $(29,37.7 \%)$, "desirable values" was very necessary $(47,61.0 \%)$ and slightly necessary $(15,19.5 \%)$, "sympathy" was very necessary $(39,50.6 \%)$ and slightly necessary $(28,36.4 \%)$, "universal literacy" was slightly necessary $(35,45.5 \%)$ and neutral $(21,26.0 \%)$, "international communication" was slightly necessary $(31,40.3 \%)$ and neutral $(27,35.1 \%)$, "self-directed exploration" was slightly necessary $(39,50.6 \%)$ and very necessary $(21,227.3 \%)$, and "convergence capability" was very necessary $(33,42.9 \%)$ and slightly necessary (30, 39.0\%).

The item that was most necessary to strengthen among all 12 items when the minimum is 1 and maximum is 5 was community spirit 4.32 ( $\mathrm{SD}=0.96)$, followed by desirable values $4.30(\mathrm{SD}=1.05)$, sympathy $4.28(\mathrm{SD}=0.95)$, convergence capability $4.16(\mathrm{SD}=0.88)$, creativity 4.11 $(\mathrm{SD}=0.83)$, civic spirit $4.10(\mathrm{SD}=0.91)$, and ration- al/critical thinking $3.94(\mathrm{SD}=1.04)($ Table 10$)$.

\section{Correlation between firm size and necessary competencies}

We conducted one-way ANOVA and Scheffe post-hoc test to examine the difference in fields that need to be strengthened depending on the number of full-time employees (Table 11). There were statistically significant differences according to the number of full-time employees in creativity, aesthetics, civic spirit, international communication, and self-directed exploration.

'Creativity' was most necessary in companies with less than 3 employees (4.39) and 4-7 employees (4.33), followed by 21-30 employees (3.00), 8-20 employees (3.60), and 31 employees or more (3.00), showing significant differences in only companies with less than 3 employees, 4-7 employees, and 20-30 employees. 'Aesthetics' showed differences among companies with less than 3 employees (3.94), 4-7 employees (3.61), and 21-30 employees (2.50). 'Civic spirit' showed differences among companies with 31 employees or more (4.33), less than 3 employees (4.30), 4-7 employees (4.22), 8-20 employees (3.67), and 20-30 employees (3.00). 'International communication' showed differences among companies with less than 3 employees (3.88), 31 employees or more (3.67), 8-20 employees (3.53), 4-7 employees (3.34), and 21-30 employees (2.50). 'Self-di-

Table 9. Descriptive statistics of importance by subcompetence

$N=77$

\begin{tabular}{|c|c|c|c|c|c|}
\hline \multirow{2}{*}{ Sub competence } & \multicolumn{5}{|c|}{ Necessity (\%) } \\
\hline & Very unnecessary & Unnecessary & Neutral & Necessary & Very necessary \\
\hline Rational critical thinkings & 1.3 & 6.5 & 19.5 & 36.4 & 36.4 \\
\hline Computing thinkings & 2.6 & 1.3 & 33.8 & 40.3 & 22.1 \\
\hline Creativity & 0.0 & 2.6 & 14.3 & 48.1 & 35.1 \\
\hline Aesthetics & 1.3 & 9.1 & 37.7 & 33.8 & 18.2 \\
\hline Community spirit & 2.6 & 1.3 & 13.0 & 24.7 & 58.4 \\
\hline Civic spirit & 1.3 & 2.6 & 18.2 & 37.7 & 40.3 \\
\hline Desirable values & 2.6 & 1.3 & 15.6 & 19.5 & 61.0 \\
\hline Sympathy & 1.3 & 1.3 & 10.4 & 36.4 & 50.6 \\
\hline Universal literacy & 1.3 & 1.3 & 26.0 & 45.5 & 26.0 \\
\hline International communication ability & 1.3 & 2.6 & 35.1 & 40.3 & 20.8 \\
\hline Self-directed exploration ability & 1.3 & 6.5 & 14.3 & 50.6 & 27.3 \\
\hline Convergence capability & 0.0 & 2.6 & 15.6 & 39.0 & 42.9 \\
\hline
\end{tabular}


Table 10. Responses to subc-ompetencies that need to be strengthened

\begin{tabular}{ccc}
\hline Sub-competence & Average & $\begin{array}{c}\text { Standard } \\
\text { deviation }\end{array}$ \\
\hline Rational critical thinkings & 3.94 & 1.04 \\
Computing thinkings & 3.73 & 0.94 \\
Creativity & 4.11 & 0.83 \\
Aesthetics & 3.52 & 1.01 \\
\hline Community spirit & 4.32 & 0.96 \\
\hline Civic spirit & 4.10 & 0.91 \\
Desirable values & 4.30 & 1.05 \\
Sympathy & 4.28 & 0.95 \\
Universal literacy & 3.89 & 0.89 \\
\hline International communication ability & 3.71 & 0.92 \\
\hline Self-directed exploration ability & 3.90 & 0.96 \\
Convergence capability & 4.16 & 0.88 \\
\hline
\end{tabular}

rected exploration' showed differences among companies with less than 3 employees (4.21), 4-7 employees (4.06), 21-30 employees (2.510), 8-20 employees (3.67), and 31 employees or more (3.67).

\section{Discussions}

Since the establishment of the Act on Fostering and Supporting Rural Convergence Industry in 2015, businesses in the 6th industries showed low expertise in management-related fields (Ma, et al., 2017) Therefore, the first priority core competencies required by experts in the 6th industry were business competencies and marketing, the second priority were marketing and operation of rural tourism and programs, and the third priority were operation of rural tourism and programs and publicity (Ma et al.

Table 11. Responses to sub-competencies that need to be strengthened according to the number of full time employees

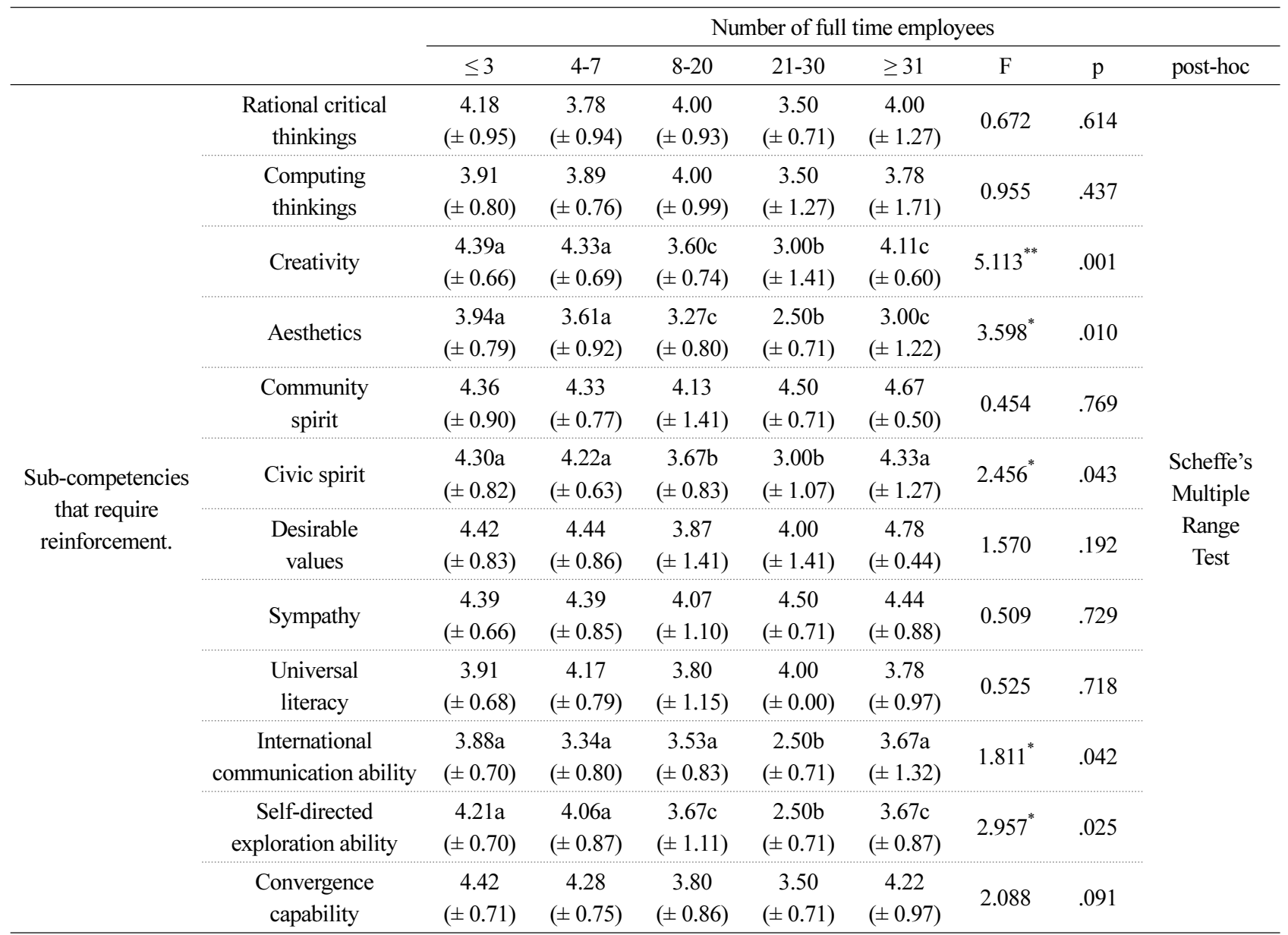

${ }^{*} p<.05, \stackrel{* *}{p} p<.01$

$\mathrm{a}>\mathrm{b}>\mathrm{c}$ : Scheffe's Multiple Range Test 
2015). As proved in this study, most companies related to the 6th industry have less than 3 employees and thus require convergence capabilities of employees to perform various tasks. To even perform tasks related to experience-based programs and publicity, aesthetics may also be required as a core competency.

Business strategies vary depending on firm size, which is represented by the number of full-time employees. In other words, for the agricultural product processing type, agricultural products, processed goods and experiences are mostly consumed within the area in the business start-up stage, but in the growth stage, it is important to explore and meet the demands at the national level beyond the regional level, and sales-related service strategies become most important in the high-speed growth stage (Kim, 2017). In the process in which agricultural products produced at farms are sold to consumers and provide experience value, the 6th industry is where tangible/intangible products and service elements are in convergence (Ahn, 2020). According to Hwang and Lee (2016) who analyzed the difference in the income generation structure depending on convergence method, the suitable convergence method varies depending on firm size. Single-bond 6th industrialization of $1+2$ and $1+3$ is suitable for the current agricultural environment in Korea for smaller firms, whereas corporations are likely to choose overall convergence that combine $1+2+3$ (Hwang and Lee 2016). Therefore, there will be a difference in ideal talent and core competencies required by firms depending on their size.

Participating in the 6th industry is becoming an alternative to creating jobs in the agro-industry. By business, business owners who belong to organizations like corporations rather than individual farms have higher demand for employment, especially in proportion to the CEO's education level and computer skills (Yi, 2016). This implies that agricultural corporations contribute greatly to youth employment. As for the regional comparison of business start-up, the competition rate of cities combined with functions of rural and urban communities is constantly increasing except metropolitan cities and Seoul-Incheon district. The competition rate in Gyeongsangnam-do is remarkably higher than other provinces (Eom et al., 2016).

In sum, considering the regional characteristics of
Gyeongnam that meets the trends of convergence and incorporation of agriculture and that recently shows active business start-up, the agricultural college of G University with less than $10 \%$ of major courses to cultivate core competency of community spirit in other departments except for two departments in the agricultural college must strengthen competencies such as community spirit, creativity, and aesthetics to increase employment in agriculture-related companies within the region.

\section{Conclusion}

\section{Conclusion}

In the survey on 77 agriculture companies, $98.7 \%$ of the respondents said additional training is necessary for new employees with a college degree to adapt to practical affairs. The first priority of education was "community spirit" $(22.1 \%)$ and the second priority was "convergence capability" (15.6\%). The most important educational goal desired by companies was "cultivating human resources with community spirit and ethical judgment", followed by "cultivating human resources with serious communication and problem-solving skills" and "cultivating human resources with scientific thinking and unique creative imagination". Sub-competencies that companies want agricultural colleges to strengthen were community spirit 4.32 ( $\mathrm{SD}=0.96)$, followed by desirable values 4.30 ( $\mathrm{SD}=1.05)$, sympathy 4.28 $(\mathrm{SD}=0.95)$, convergence capability $4.16(\mathrm{SD}=0.88)$, creativity $4.11(\mathrm{SD}=0.83)$, civic spirit $4.10(\mathrm{SD}=0.91)$, and rational/critical thinking $3.94(\mathrm{SD}=1.04)$. There was a significant difference in sub-competencies that require reinforcement depending on the number of full-time employees. 'Creativity' was most necessary in companies with less than 3 employees (4.39) and 4-7 employees (4.33), 'aesthetics' in companies with less than 3 employees (3.94) and 4-7 employees (3.61), and 'civic spirit' in companies with 30 employees or more (4.33).

\section{Suggestions}

First, agricultural education has thus far been focused 
on developing agricultural skills that can be applied immediately, but the roles that must be performed by agricultural majors in the future agrifood system according to the current convergence characteristics of agriculture are to raise the need for new competencies and develop new ways of professional thinking. In designing agricultural curriculums in higher education, it is necessary to provide program contents that teach future agricultural majors the competencies necessary for adapting to the needs of agriculture companies that are constantly changing through interdisciplinary education. Core competencies that are the major courses in the agricultural department of G University are scientific thinking, solving problems, and unique creative imagination, but this implies that it is necessary to reinforce the mandatory courses to enhance competencies such as community spirit, creativity, and aesthetics of undergraduate students.

Second, since there is insufficient education that aims to promote community spirit as a core competency in agricultural major. To supplement this, it is necessary to enhance the core competency of community spirit by adjusting the teaching method from the conventional lecture style to a teaching method that emphasizes cooperation such as PBL.

Third, since extracurricular programs emphasize autonomy and diversity relatively more than regular curriculums, extracurricular programs can be used as selective activities without credits to overcome the limitations of regular curriculums and enhance core competencies such as creativity, aesthetics, and community spirit.

\section{Limitations}

This study conducted a survey on the demand for core competencies of ideal talent demanded from agricultural colleges by small and mid-sized agriculture-related companies. It is necessary to also apply methods such as AHP (analytic hierarchy process) to prioritize the decisions or in-depth interviews with managers of the companies or professors. Second, it is necessary to examine the ideal talent demanded by companies depending on the type of agricultural convergence by increasing the sample size to improve field adaptability of this study. Furthermore, further research must combine the demands of the industry and opinions of the subjects of education after conducting a satisfaction survey on the subjects of agricultural education.

\section{References}

Adams, C. J. 2012. 'Soft skills' seen as key element for higher Ed. Edu. Week. 32(12):1-2. https://eric.ed.gov/?i $\mathrm{d}=\mathrm{EJ} 1000114$

Ahn, K.S. 2020. A study on the characteristics of agricultural design through case analysis of rural convergence industry. J. Ind. Des. Stud. 14(3):41-51. http://pdf.medrang.co.kr/ kaid/2020/014/kaid014-03-05.pdf

Baek, P.G. 2013. A Study on the Relationships and Characteristics between Korean Collegiate Essential Skills and Undergraduates' Individual Variant Factors. Korean J. Gen. Educ.7(3):349-387.

Boyatzis, R.E. 2008. Competencies in the 21st century. Journal of Management Development, 27(1):5-12. https://doi.org/ 10.1108/02621710810840730

Bryant, L.H., K. Niewolny, S. Clark, and C.E. Watson, C.E. 2014. Complicated spaces: Negotiating collaborative teaching and interdisciplinarity in higher education. J. Effective Teach. 14(2):83-101.

Colclasure, B. 2020. Entry-Level Workplace Competencies Needed by Graduates of a Community College Agriculture Program: A Midwest Case Study Using the Delphi Technique. J. Res. Technical Careers. 4(2):3-23. https:// doi.org/10.9741/2578-2118.1083

Eom, J.Y., K.S. Kim, and J.E. Lim. 2016. The Changes in Rural Labor Market and Policy Tasks. Korea Rural Econ. Inst. repository. 774:1-166. Retrieved from http://rep ository.krei.re.kr/handle/2018.oak/21770

Hilimire, K., S. Gillon, B.C. McLaughlin, B. Dowd-Uribe, and K.L. Monsen. 2014. Food for thought: Developing curricula for sustainable food systems education programs. Agroecology and Sustainable Food Systems. 38(6):722-743. https://doi.org/10.1080/21683565.2014.881456

Hwang, J.H., and S.W. Lee. 2016. Classification of 6th industrialization of agriculture and effect on farm household income. J. Rural Dev. 39(4): 1-28.

Hwang, J.Y. 2020. A Case of Developing a Competency 
model for the revision of the dentistry education curriculum on the competency-based. Journal of Digital Convergence. 18(11):347-354. https://doi.org/10.14400/ JDC.2020.18.11.347

Hwang, S.H. 2018. Analysis of Core Competencies in Engineering Students and Utilization of Extracurricular Activities. J. Eng. Educ. Res. 21(6):63-73.

Jin, M.S., Y.M. Son, and H.J. Chu. 2011. A Study on Development Plan of K-CESA for College Education Assessment. J. Educ. Adm. 29(4):461-486.

Kim, D.J., and S.Y. Kim. 2017. Understanding and Issues on core competency and competency-based curriculum in higher education. J. Core Competency Educ. Res. 2(1):23-45. https://doi.org/10.52616/JCCER.2017.2.1.23

Kim E.J., and M.H. Seong. 2017. Educational Needs of Industry in Core Competencies and General Education at Universities -Focused on the Health Care Industry. Korean J. Gen. Educ. 11(2):121-145.

Kim, H.S., S.Y. Park., and S.B. Cha. 2015. Structural equation analysis of Factors related to learning transfer with agricultural college specialized management program for university students. J. Agric. Educ. Hum. Resour. Dev. 47(4): 1-26. https://doi.org/10.23840/agehrd.2015.47.4.1

Kim, J.T. 2017. Exploring the Management Component of Rural Small Business in the 6th Industry at Each Stage of Growth. Asia Pac. J. Bus. Ventur. Entrep. 12(6):123-138.

Kim, J.T. and S.E. Bae. 2014. Employment Rate of Graduates of Agricultural Science Colleges in the Fields of Agro-industry. J. Agric. Ext. Community Dev. 21(4): 1093-1124. https://doi.org/10.12653/jecd.2014.21.4.1093

Lee, M.R., and N.R. Kim. 2018. Development and Validation of a Scale for Diagnosing the Core Competency of University Students: M University Case Study. J. Korean Soc. Mar. Environ. Saf. 24(5): 576-582. https://doi.org/10. 7837/kosomes.2018.24.5.576

Lee, S.Y. 2018. The Effect of Planned Behavior of University Student who Participates in Education for Starting Agricultural Business on Entrepreneurship and Will to Start the Business. Asia Pac. J. Bus. Ventur. Entrep. 13(1): 145-155.

Lee, S.E., and K.H. So. 2019. Analysis of Change Trends on OECD's Competencies Frameworks for Curriculum Redesign: Focused on "Education 2030". J. Curric. Stud. 37(1):139-164.
Ma, S.J., J.I. Kim, and K.S. Jung. 2015. Survey on the professional manpower of the 6th industrialization certified company. Korea Rural Econ. Inst. repository. D_R750_1: 1-81. Retrieved from http://repository.krei.re.kr/handle/2 018.oak/21484

Ma, S.J., J.Y. Eom, and K.I. Kim. 2017. Possibility and challenges of creating youth employment in the agricultural industry. Korea Rural Econ. Inst. repository. 148:1-14. Retrieved from http://repository.krei.re.kr/handle/2018.o $\mathrm{ak} / 21926$

OECD. 2005. The definition and selection of key competencies: Executive summary. Paris, France:OECD.

Oh, E.J. 2012. Work-Competencies and Competency-based Curriculum Development. J. Korea Contents Assoc. 12(2): 517-531. https://doi.org/10.5392/JKCA.2012.12.02.517

Paek, S.S. 2020. A Study on the Problem and Improvement of Core Competency-Based Liberal Arts Education. Korean J. General. Edu. 14(3):11-23. https://doi.org/10. 46392/kjge.2020.14.3.11

Park, S.J., and Y.S. Song. 2016. A Study on Development of a Core competencies tool of University Students According to Specialized University. J. Voca. Educ. Train. 19(2):79-107.

Park, J.M., C.S. Kim, J.H. Kim, J.Y. An, and E.Y. Pyo. 2015. Strategy for Improving Core Nursing Competencybased Education. J. Korean acad. soc. nursing educ. 21(3): 426-439. https://doi.org/10.5977/jkasne.2015.21.3.426

Rychen, D. 2003. Investing in Competencies-but which competencies and for what? A contribution to the ANCLI. In AEA Conference on Assessment Challenges for Democratic Society. Lyon:OECD Project DeSeCo. Retrieved from https://www.oecd.org/pisa/35070367.pdf

So, K.H. 2007. Competency in the Context of Schooling: It's Meaning and Curricular Implications. J. Curric. Stud. 25(3):1-22. https://doi.org/10.15708/kscs.25.3.200709.001

Valley, W., H. Wittman, N. Jordan, S. Ahmed, and R.E. Galt. 2018. An emerging signature pedagogy for sustainable food systems education. Renew. Agric. Food Syst. 33(5):467-480. https://doi.org/10.1017/S17421705 17000199

Yi, H.M. 2016. A Study on Determinants of 'Employment' -Focused on 6th industrialization-. Korean J. Food Mark. Econo. 33(3):109-133. 